doi: 10.32620/oikit.2020.87.06

УДК 62.822

А. Б. Жукевич, О. А. Жукевич*

\title{
Синтез і напівнатурне моделювання системи управління гідроприводу з ковзними режимами
}

\author{
Національний аерокосмічний університет ім. М. Є. Жуковського «Харківський \\ авіаційний інститут» \\ *Харківський національний університет радіоелектроніки
} керування релейного типу з ковзними режимами. Об'ємний гідропривод використовують у сільськогосподарських, будівельних, транспортних машинах, вугільних комбайнах, бурових установках, літаках, військовій техніці та ін. Гідравлічні об'ємні привода мають ряд переваг, найважливішими з яких є можливість отримання великих зусиль, плавність ходу, мала інерційність гідромашин, порівняно високий ККД (до 80\%), висока надійність. У той же час йому властиві ряд недоліків, головним з яких є зміна властивостей робочої рідини в процесі експлуатації і під впливом зовнішніх чинників. До недоліків також можна віднести і втрати масла в гідросистемі, забруднення рідини в процесі експлуатації. Зазначені недоліки можуть призвести до втрати якості управління, втрати точності, швидкості відпрацювання заданих керуючих впливів. Одним із класів систем, які структурно забезпечують високу динамічну точність, є системи, що працюють у ковзному режимі. Крім того, за рахунок введення ковзного режиму в ряді випадків вдається підвищити ступінь астатизму системи, а отже, і поліпшити якість відтворення вхідного завдання. Запропоновано реалізацію системи керування гідроприводом, інваріантного до параметричних і зовнішніх збурень шляхом використання ковзних режимів. Для дослідження запропонованої системи управління гідроприводом побудовано напівнатурну модель розробленої системи, у якій замість натурного об'єкта гідроприводу використовують його математичну модель, у той же час сама система керування реалізована фрізично такою, яка буде використана у реальному пристрої. Напівнатурне моделювання дозволило відповісти на запитання реалізації ковзних режимів при керуванні гідроприводом об'ємного регулювання за допомогою електродвигуна постійного струму. Досліджено поведінку системи керування гідроприводом при зміні параметрів об'єкта управління (моменту інерції, в'язкості масла), яке показало, що зміна коефіцієнта демпфірування в досить широких межах (до 50\% від розрахункового) не призводить до зриву ковзних режимів, якість процесів регулювання суттєво не погіршується. У той же час зміна до 100\% коефіцієнта може призвести до нестійкості системи керування, що дозволяє зробити висновок про налагодження регулятора положення на менший 3 можливих коефіцієнтів демпфірування. Також зроблено дослідження на можливість цифрової реалізації синтезованого закону управління шляхом введення в контур управління часової затримки, яка можлива при використанні мікропроцесорного обчислювача.

Ключові слова: гідропривод об'ємного регулювання; ковзний режим; електродвигун постійного струму; інваріантність; напівнатурне моделювання; математична модель, дослідження системи з ковзним режимами.

\section{Вступ}

Постановка задачі. Гідроприводи є виконавчими елементами машин і механізмів, де їх використовують. Частіше за усе це силові елементи, системи керування котрих мають зворотні зв'язки за швидкістю пересування та за положенням механізму. Таким чином, ці системи $\epsilon$ позиційними або слідкуючими. Слідкуючі системи згаданих об'єктів повинні забезпечувати необхідні точності відпрацювання програмних впливів, мати стабільні задані 
динамічні характеристики, працювати, незважаючи на зміни параметрів як самого об'єкта управління (моменти інерції, витоку масла в дозволених межах, коливань живлячої напруги, нестабільності швидкості приводних електродвигунів та ін.), так і зміни в навколишньому середовищі (зміна температури, яка призводить до коливань в'язкості рідини, коливань моментів опору за рахунок природних явищ, наприклад вітру чи дощу). Таким чином, потрібно створити таку систему керування, яка була би інваріантною до параметричних змін об'єкта керування та до координатних впливів.

У ряді робіт [1, 2] запропоновано створення вдосконалених систем керування, які забезпечують необхідні статичні та динамічні характеристики гідроприводів. У цих роботах розроблено математичні моделі гідроприводів, які дозволяють дослідити пропоновані системи керування. У роботі [3] запропоновано вибір схеми та параметрів гідроприводу (синтез) на основі дискретного керування 3 обгрунтуванням методики вибору оптимальних параметрів системи керування. У цій роботі також доказ працездатності системи керування виконується на базі математичного моделювання разом із випробуванням дослідного зразка. У той же час у цих роботах (як і у багатьох інших, які присвячені гідроприводам), не досліджено чутливість систем керування до зміни параметрів гідроприводів і зміни зовнішніх впливів на роботу цих систем. Як сказано вище, від цього залежить якість керування в широкому діапазоні параметричних і координатних впливів.

Мета роботи. За допомогою відомих принципів проектування електроприводів методами аналітичного конструювання регуляторів спроектувати систему керування гідроприводом об'ємного регулювання 3 ковзними режимами, яка дозволяє, як відомо [4 - 7], побудувати систему, інваріантну до параметричних і координатних збурень. Для доказу існування ковзних режимів у системі гідроприводу об'ємного регулювання розробити напівнатурну модель створеної системи управління, яка буде містити математичну модель гідроприводу об'ємного керування та реальну систему управління, реалізовану на операційних підсилювачах та включає підсилювач потужності транзисторах, електродвигун постійного струму та редуктор, понижуючий швидкість електродвигуна. Фізична реальна система управління повинна замикатися на лінійний змінний резистор (який імітує роботу похилого диску), вихідний сигнал якого керує математичною моделлю об'єкта. Математична модель при цьому повинна працювати у реальному часу.

\section{1. Математичний опис гідроприводу об'ємного керування}

Об'єктом управління виступає позиційна система гідроприводу, що працює в режимах як відпрацювання заданих переміщень, так і в режимах стеження за вхідним завданням кута переміщення. Фізично це є платформа, яка обертається на 360 градусів з метою спостереження за небесними тілами, що рухаються з різною змінною швидкістю, тобто працює в режимах позиціонування і слідкування за вхідним сигналом. У той же час даний пристрій може використовуватися у механізмах роботів, які працюють у режимах позиціювання у задане положення (де можлива широка зміна моментів інерції за рахунок підйому та перенесення різних вантажів).

Функціональну схему гідроприводу об'ємного регулювання з елементами управління похилим диском приведена на рис. 1. 


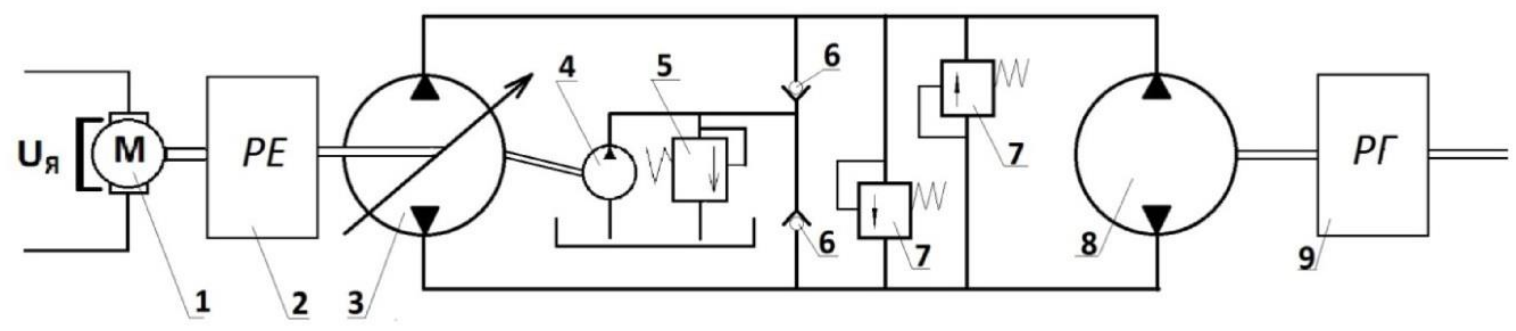

Рис. 1. Функціональна схема гідроприводу

На схемі рис. 1 позначено: 1 - електродвигун постійного струму управління похилим диском, 2 - редуктор, що знижує швидкість обертання електродвигуна, 3 - гідронасос об'ємного регулювання з похилим диском, 4 - система підживлення (гідронасос) для відновлення кількості масла в основному контурі гідроприводу, 5 - запобіжний клапан з резервуаром, куди скидається масло при перевищенні тиску в магістралі гідроприводу, 6 - зворотний клапан, 7 запобіжні клапани, 8 - гідромотор, 9 - редуктор переміщення механізму.

Як об'єкт управління виступає гідропривод об'ємного регулювання ГСП90, як електродвигун використовується двигун постійного струму ДПР-62 3 постійними магнітами збудження. На основі експериментальних досліджень визначені такі значення параметрів об'єкта управління:

$$
\begin{array}{lll}
k_{1}=2.56 \cdot 10^{-3} & - & \text { коефріцієнт передачі редуктора вихідного вала; } \\
k_{2}=6.74 \cdot 10^{-3} & - & \text { коефріцієнт передачі редуктора електродвигуна; } \\
k_{2}=162.37 c^{-1} & - & \text { коефріцієнт підсилення гідроприводу; } \\
T_{2}=0.1 c & - & \text { стала часу гідроприводу; } \\
\xi=1.2 & - & \text { коефіцієнт демпфірування гідроприводу ; } \\
c \Phi=0.1 B \cdot c & - & \text { коефріцієнт потоку електродвигуна; } \\
T_{\mathcal{M}}=0.08 c & - & \text { механічна стала часу електродвигуна. }
\end{array}
$$

Математичний опис наведеної схеми гідроприводу з різними ступенями деталізації та спрощення неодноразово наводився в наукових статтях, наприклад [8 - 10], тому наведемо систему диференціальних рівнянь, що описують об'єкт управління:

$$
\begin{aligned}
& d x_{1} / d t=k_{1} \cdot x_{2} \\
& d x_{2} / d t=x_{3} \\
& d x_{3} / d t=\left(k_{2} / T_{2}^{2}\right) \cdot x_{4}-\left(2 \xi / T_{2}\right) \cdot x_{3}-\left(1 / T_{2}^{2}\right) \cdot x_{2} \\
& d x_{4} / d t=k_{2} \cdot x_{5} \\
& d x_{5} / d t=\left(1 / c \Phi T_{\mathcal{M}}\right) \cdot U_{y}-\left(1 / T_{\mathcal{M}}\right) \cdot x_{5},
\end{aligned}
$$

де $x_{1} \ldots x_{5}-$ координати гідроприводу, а саме:

$$
x_{1}-\text { вихідний кут повороту механізму; }
$$




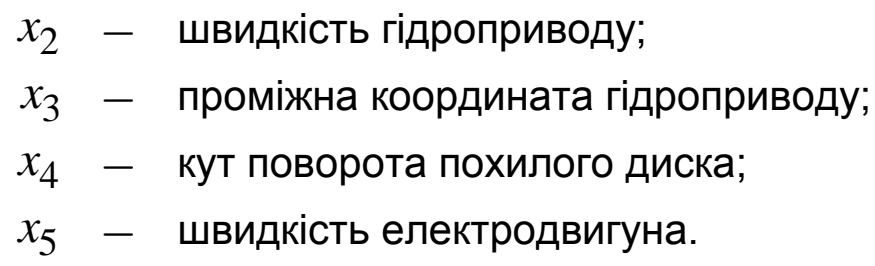

Математичну модель гідроприводу, відповідно до рівнянь (1) показано на рис. 2. Згідно до наведених диференціальних рівнянь об'єкта керування для спрощення операції синтезу системи управління електрогідроприводом було зроблено допущення при опису об'єкта:

- керуючий електродвигун постійного струму поданий ланкою першого порядку (в дійсності це об'єкт другого порядку з сталою часу якірного ланцюга та електромеханічною сталою часу двигуна);

- момент статичного опору золотника гідроприводу не враховується;

- момент статичного опору на вихідному валу гідроприводу не враховується.

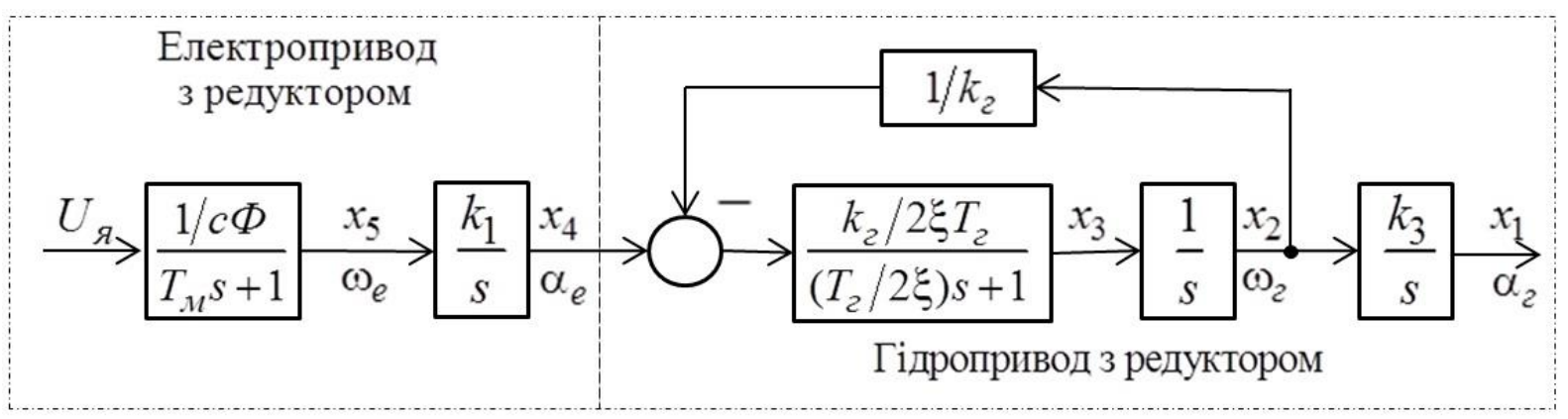

Рис. 2. Математична модель електрогідроприводу

\section{2 Синтез системи управління 3 ковзними режимами}

Процедуру синтезу системи управління з ковзними режимами досить докладно неодноразово описували в наукових статтях [5 - 7]. Послідовність конструювання системи управління полягає в такому:

- вводять відносні одиниці відповідних координат об'єкта управління $y_{i}=\frac{x_{i}}{x_{i \max }}-\left(x_{i \max }\right.$ - максимально допустиме значення ї координати);

- вводять змінні збуреного руху шляхом заміни змінних $y_{i}$ на змінні збуреного руху $\eta_{i}=y_{i}-y_{i}^{0}\left(y_{i}^{0}-\right.$ відповідна координата незбуреного руху).

Після проведення описаних вище перетворень системи рівнянь (1) отримано нові коєфріціенти системи:

$$
\begin{aligned}
& b_{12}=k_{1} \frac{x_{2 \max }}{x_{1 \max }} ; b_{23}=\frac{x_{3 \max }}{x_{2 \max }} ; b_{32}=-\frac{1}{T_{2}^{2}} \frac{x_{2 \max }}{x_{3 \max }} ; b_{33}=-\frac{2 \xi}{T_{2}} ; b_{34}=\frac{k_{2}}{T_{2}^{2}} \frac{x_{4 \max }}{x_{3 \max }} ; \\
& b_{45}=\frac{x_{5 \max }}{x_{4 \max }} ; b_{55}=-\frac{1}{T_{r}} ; m_{5}=\frac{1}{\left(c \Phi T_{\mathcal{M}}\right)} \frac{U_{\max }}{x_{5 \max }},
\end{aligned}
$$

а також систему диференціальних рівнянь збуреного руху системи: 


$$
\begin{aligned}
& \frac{d \eta_{1}}{d t}=b_{12} \cdot \eta_{2} ; \\
& \frac{d \eta_{2}}{d t}=b_{23} \cdot \eta_{3} ; \\
& \frac{d \eta_{3}}{d t}=b_{32} \eta_{2}+b_{33} \eta_{3}+b_{34} \eta_{4} ; \\
& \frac{d \eta_{4}}{d t}=b_{45} \cdot \eta_{5} ; \\
& \frac{d \eta_{5}}{d t}=b_{55} \eta_{5}+m_{5} \cdot U_{y} .
\end{aligned}
$$

У результаті описаних перетворень отримано систему лінійних диференціальних рівнянь (2), що описують рух об'єкта управління. Для забезпечення мінімуму інтегральних квадратичних відхилень регульованої координати (в даному випадку - кутового положення механізму гідроприводу) від заданого за наявності обмеження на енергію управління необхідно з безлічі кусково-неперервних фрункцій, обмежених рівнянням $|U| \leq U_{y \max }$ знайти алгоритм оптимального управління регулятора положення, який в сукупності 3 об'єктом управління (2) утворює стійку систему і гарантує задану якість управління, мінімізуючи фрункціонал [5]

$$
J=\int_{0}^{\infty}\left(a_{1} \eta_{1}^{2}+c_{1} U_{1}^{2}\right) d t
$$

на траєкторії руху системи (2) з будь-якого початкового стану $\eta_{i}(0)$ в початок координат $\eta_{i}=0$. У функціоналі якості (3) $c_{1}, a_{1}$ - вагові коефіцієнти, що визначають показники якості системи управління. Синтез подібних завдань розглядався неодноразово в літературі [5 - 7], в якій було доведено, що очікуваний закон управління буде знайдений у вигляді

$$
U_{p n}=U_{y \max } \operatorname{sign}\left(b_{0} x_{1}^{0}-\sum_{k=1}^{5} b_{k} x_{k}\right),
$$

де $x_{1}^{0}$ - задане значення координати кутового положення механізму електрогідроприводу;

$b_{k}$ - коефіцієнти зворотних зв'язків за внутрішніми координатами електрогідроприводу;

$x_{k}$ - координати електрогідроприводу, описані в рівняннях (1).

Таким чином, закон управління релейного регулятора, який реалізує ковзний режим виглядає таким чином:

$$
U_{p n}=U_{y \max } \operatorname{sign}\left(b_{0} x_{1}^{0}-b_{1} x_{1}-b_{2} x_{2}-b_{3} x_{3}-b_{4} x_{4}-b_{5} x_{5}\right) .
$$

Розрахунок коефіцієнтів $b_{k}$ згідно $з$ експериментальними параметрами гідроприводу, наведеними раніше, та згідно з формулами (2) наведено нижче: 


$$
\begin{aligned}
& b_{0}=1 \cdot 10^{-1} ; b_{1}=1.1 \cdot 10^{-2} ; b_{2}=2.4 \cdot 10^{-2} ; b_{3}=4.5 \cdot 10^{-3} ; \\
& b_{4}=7 \cdot 10^{-3} ; b_{5}=1.3 \cdot 10^{-3} .
\end{aligned}
$$

Структурну схему системи автоматичного управління електрогідроприводом з реалізацією ковзних режимів показано на рис. 3.

\section{3 Напівнатурне моделювання синтезованої системи управління гідроприводу з ковзними режимами}

Задачею моделювання синтезованої системи управління було:

- доказати існування ковзних режимів системи управління гідроприводом об'ємного регулювання;

- дослідити поведінку системи управління при впливі на об'єкт управління збурюючих чинників.

На рис. 4 показано функціональну схему стенда для випробування лабораторного макета системи управління позиційним електрогідроприводом, при побудові лабораторного макета використано метод напівнатурного моделювання. Суть методу полягає в тому, що до моделюючого комплексу разом з математичною моделлю деяких ланок системи включається реальна апаратура системи управління. Математична модель відтворює ту частину системи, яка не може бути реалізована в лабораторних умовах або реалізація якої недоцільна. 3 огляду на складність технічної реалізації фрізичної моделі силового гідроприводу в випробувальному стенді використано аналогову модель на операційних підсилювачах $A 1 \ldots A 3, A W 3$, що являють собою суматори і інтегратори. Для того щоб можливо було відслідковувати процес формування помилки відпрацювання заданого значення $\alpha_{0}$ (сигналу $\Delta \alpha$ ) у систему управління введено суматор $A W 1$, який виділяє помилку для можливості фріксувати ії на осцилограмах. Математична модель працює в натуральному масштабі часу. Вхідним сигналом для моделі $\epsilon$ напруга, що знімається з лінійного потенціометра $B Q$, що імітує кут повороту похилого диска гідронасоса об'ємного регулювання. Движок потенціометра приводиться в рух через редуктор від двигуна $\mathrm{M}$, який управляється від фрізичного лабораторного макета позиційної системи управління. До складу лабораторного макета входить силовий транзисторний перетворювач UM , релейний регулятор $\mathrm{AQ}$, підсумовуючі підсилювачі $A W 1, A W 2$.

\section{4 Дослідження напівнатурної моделі позиційного електрогідравлічного приводу з ковзними режимами}

Згідно з постановкою задачі для підтвердження існування ковзних режимів та якості керування було досліджено напівнатурну модель (рис. 4). Усі експерименти було зафріксовано у вигляді осцилограм роботи системи при різних завданнях та показниках параметричних даних електрогідроприводу. На рис. 5 приведено осцилограму відпрацювання гідроприводом заданого переміщення. 


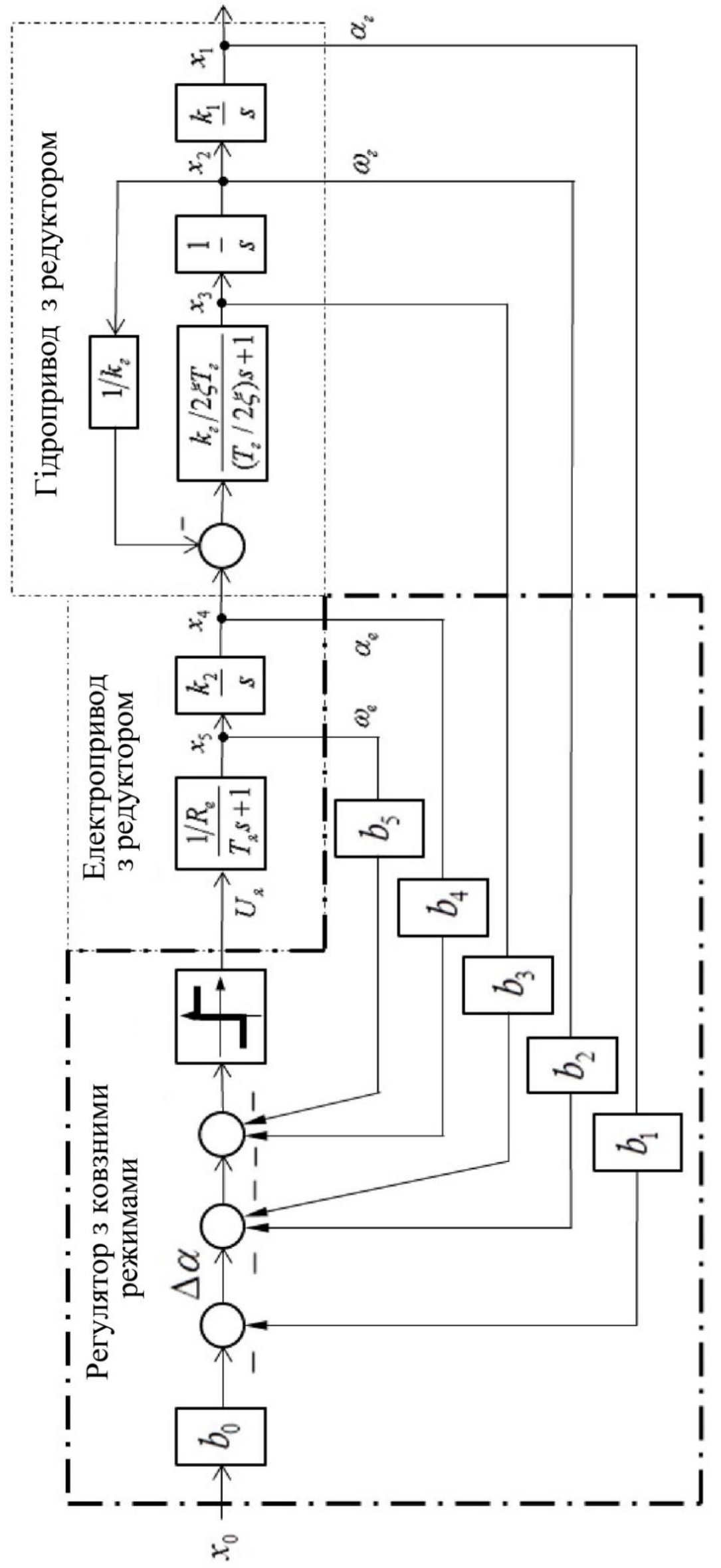

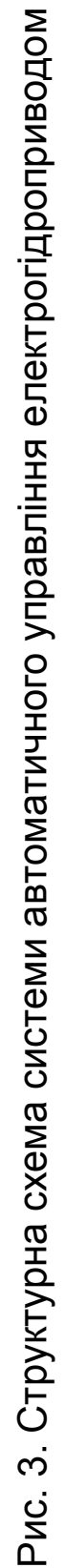




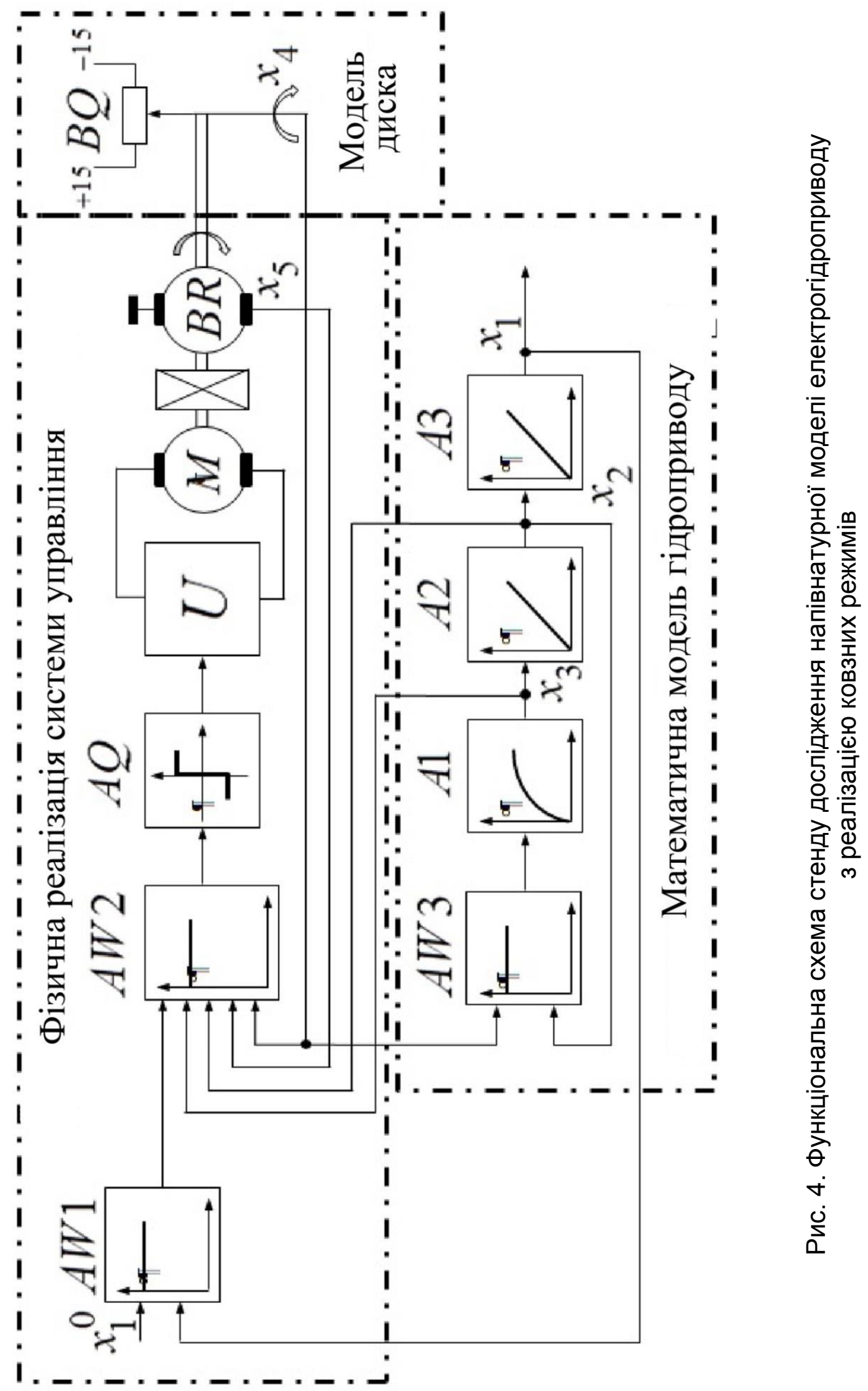


Показана на рисунку крива $\Delta \alpha(t) \in$ вихідний сигнал пристрою порівняння сигналу завдання та поточного положення вала механізму. Лінійна зона пристрою порівняння становить близько 2 градусів кута, тому при великих похибках $\Delta \alpha(t)$ цей пристрій має обмеження. Слід відзначити, що при оптимальних з точки зору квадратичного функціоналу (3) коефіцієнтах зворотного зв'язку система управління забезпечує відпрацювання заданого переміщення близько до найкращого з точки зору швидкодії.

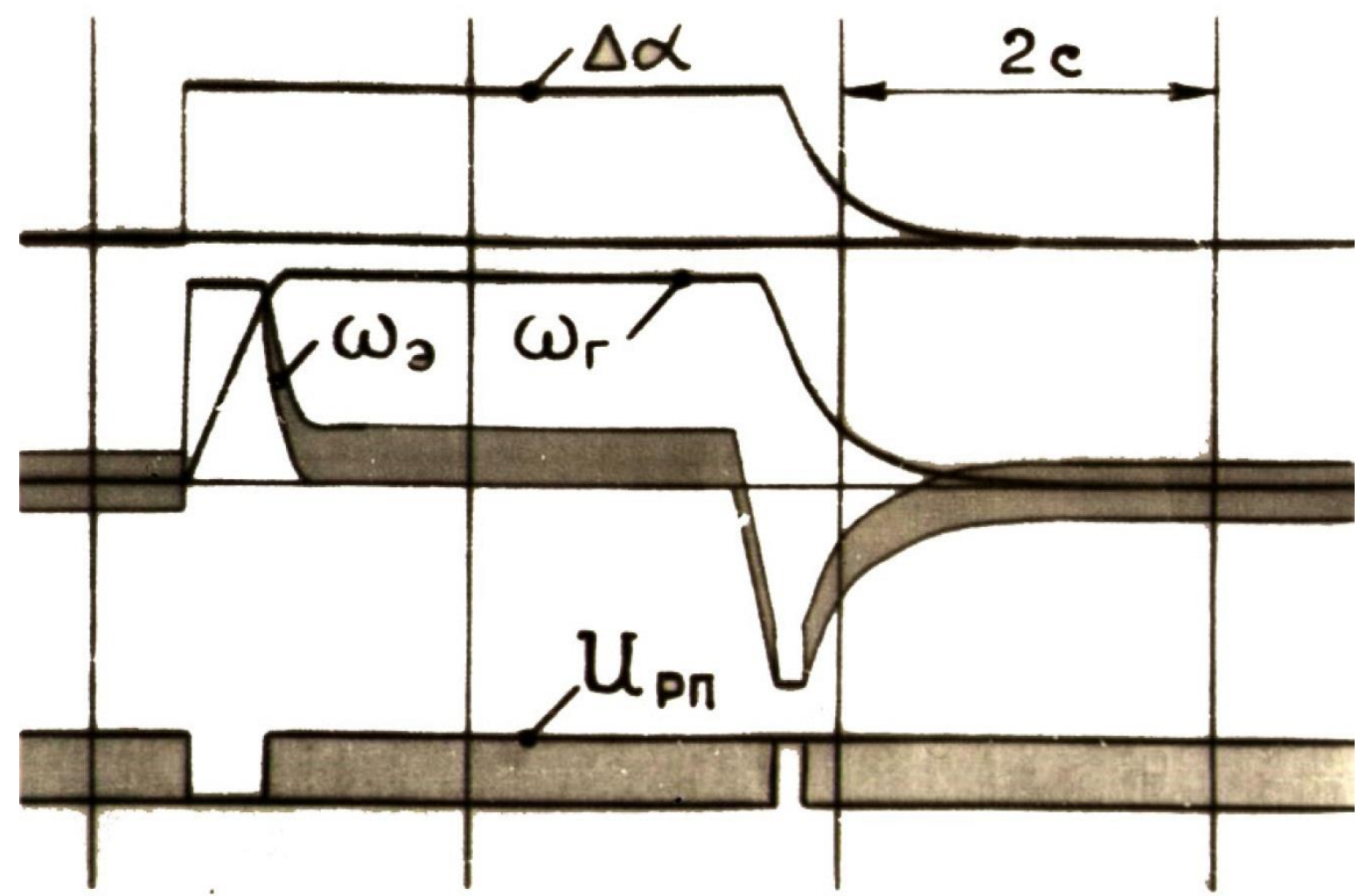

Рис. 5. Осцилограма оптимального відпрацювання завдання на кут переміщення більше 2 градусів

Дійсно, фазова траєкторія процесу позиціювання в просторі головної координати $(\alpha(t)$ та її похідних (швидкість гідромотора та швидкість електродвигуна) проходить поблизу кордонів області допустимих значень координат $\omega_{e}= \pm \omega_{e \max } ; \omega_{2}=\omega_{2 \max }$. Наявність ділянки неоптимального за швидкодією переходу від однієї області до іншої пояснюється тим, що сигнал управління формується як релейна фрункція лінійної фуннції координат. Зменшення швидкості керуючого двигуна до нуля після повороту похилого диску гідронасоса на максимальний кут пояснюється дією зворотних зв'язків по цьому куту та швидкості гідромотора. Регулятор положення, після того як гідромотор розігнався з максимальним прискорення, входить в ковзний режим. При цьому система управління $є$ розімкнутою по положенню, так як пристрій порівняння по куту знаходиться в режимі обмеження. Регулятор положення при цьому працює як регулятор швидкості гідроприводу, сприймаючи сигнал $\Delta \alpha(t)$, як сигнал завдання за швидкістю гідроприводу. 
При підході до заданого положення контур положення замикається по куту механізму та релейний регулятор знову входить у ковзний режим і забезпечує точну зупинку механізму в заданому положенні. Частота ковзного режиму визначається в основному шириною петлі гістерезису релейного регулятора і коефіцієнтом зворотного зв'язку за швидкістю електродвигуна та становить 500...800 Гц при даних параметрах системи.

На рис. 6 показано дві осцилограми відпрацювання завдання на кут переміщення при зміні коефіцієнта демпфірування гідроприводу у два рази у сторону зменшення $(\mathrm{a}-\xi=0.8)$ і у сторону збільшення (б $-\xi=1.8)$. Як видно з графріків перехідних процесів, ковзні режими не зриваються ні при збільшенні, ні при зменшенні сталої часу гідроприводу. Суттєво змінюється характер перехідних процесів гідроприводу: вони стають або більш коливальними (при зменшенні коефіцієнта), або більш затягнутими (при збільшенні коефіцієнта).

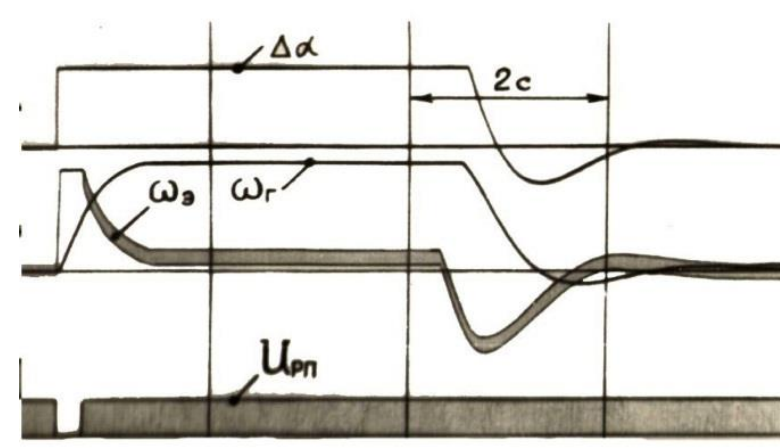

a

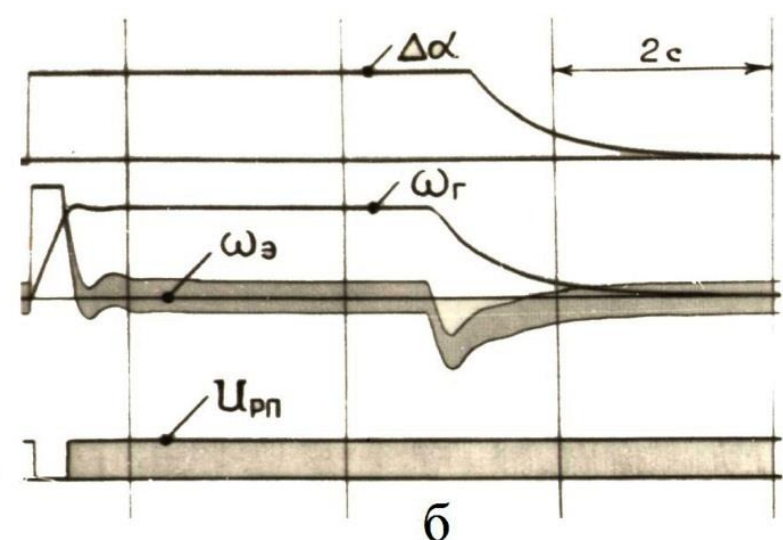

6

Рис. 6. Відпрацювання завдання на кут переміщення при зміні параметрів об'єкта керування

(а - зменшення, б - збільшення коефіцієнту демпфірування гідроприводу)

При подальшому зменшенні коефіцієнта демпфірування (до величин $\xi=0.4 . .0 .6)$ в системі суттєво підвищується коливальність, причому при низьких значеннях його система може стати нестійкою. Таким чином, можна стверджувати, що система управління з ковзним режимом інваріантна до зміни параметрів гідроприводу в досить широких межах. 3 точки зору зміни коефріцієнта демпфірування, до цього можуть призвести зміни як зовнішніх чинників (зміни моменту інерції на валу механізму), так і властивостей робочої рідини за рахунок, наприклад, зміни зовнішньої температури, забруднення під час роботи механізму. Однак ці дослідження показали, що налагодження регулятора позиціювання потрібно налаштовувати на якомога менший коефіцієнт демпфірування, це унеможливить втрату стійкості роботи системи в широких межах температур.

Синтезована система управління 3 регулятором виду (4) прекрасно підходить для реалізації цифрового управління, оскільки в розрахунках відсутні складні обчислення, тобто час на прорахунок керуючого впливу буде мінімальним. У той же час використання цифрових датчиків і обчислювачів вносить в канал зворотного зв'язку чисте часове запізнення, яке може позначитися на стійкості системи. На рис. 7 показано дослідження введення 
навіть відносно великого запізнення ( $\tau=0.1 c$ на рис. 7 ,а та $\tau=0.2 c$ на рис. $7,6)$, яке показує, що введення $\tau$ не позначається на статичній точності системи управління, проте призводить до збільшення коливальності, збільшення часу перехідного процесу.

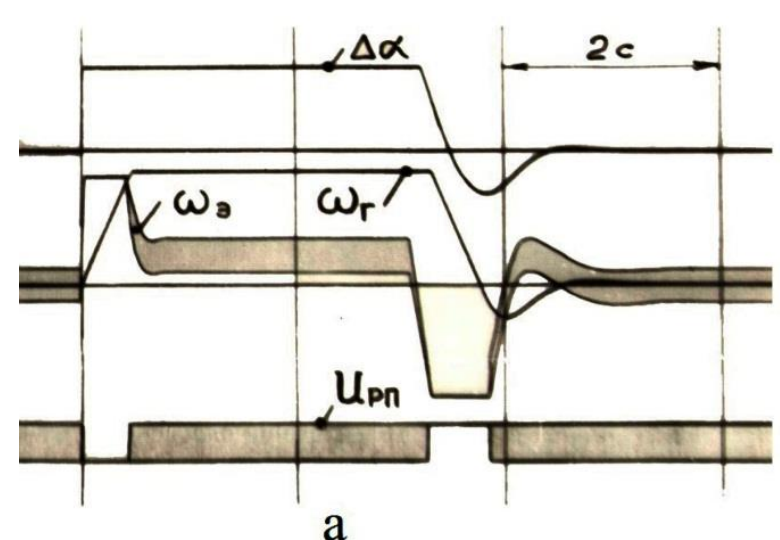

a

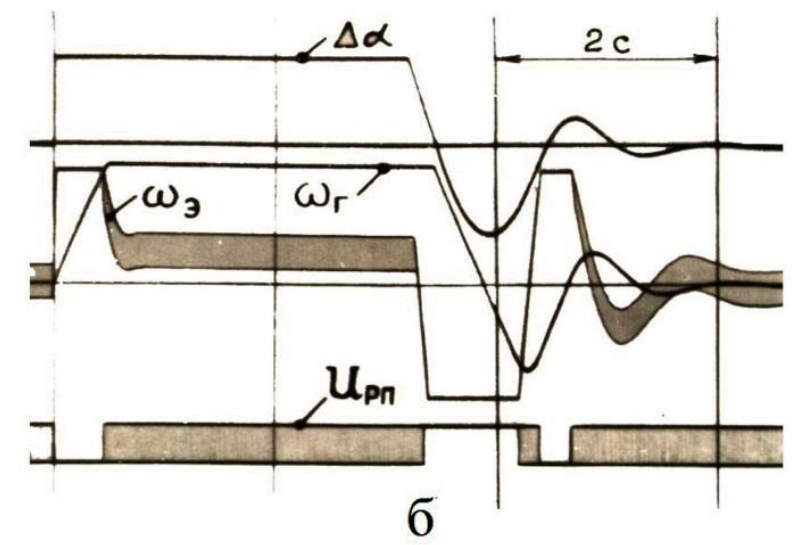

6

Рис. 7. Графрік відпрацювання завдання на положення механізму за наявності запізнення в системі за рахунок наявності обчислювача

На рис. 8 показано графрік відпрацювання завдання на слідкування за кутом переміщення 3 відносно малою швидкістю (3 кут.хв/сек) і відносно високою швидкістю (0,5 кут.град/сек). Відпрацювання лінійно наростаючого сигналу відбувається з постійною помилкою по положенню, яка пропорційна швидкості зміни вхідного сигналу. В системі присутні ковзні режими, які при відпрацюванні завдання не зриваються. Швидкість електродвигуна в процесі відпрацювання під впливом ковзного режиму залишається такою, що дорівнює нулю, лише в момент пуску і гальмування гідроприводу електродвигун провертає валик гідронасоса на відповідну величину.

\section{Висновки}

Таким чином, розглянуто питання побудови системи управління електрогідроприводу об'ємного регулювання з реалізацією ковзних режимів у контурі управління. Для цього складено лінійну математичну модель гідроприводу об'ємного регулювання як елемента електрогідравлічної системи управління. На основі методів аналітичного конструювання регуляторів синтезовані закони управління електрогідравлічним приводом. Синтезований регулятор положення забезпечує роботу електрогідравлічного приводу в режимі позиціонування і стеження за лінійно змінним сигналом завдання з постійною швидкістю. Синтезована система управління відноситься до класу структур, стійких при нескінченно великому коефіцієнті посилення, що забезпечує високі динамічні та статичні показники при низькій чутливості до параметричних і координатних збурень.

Для дослідження синтезованої системи управління було розроблено структуру напівнатурного моделювання електрогідроприводу об'ємного регулювання, в якій використано фрізичну реалізацію системи керування включно з двигуном постійного струму та математичну модель гідроприводу, яка працює в режимі реального часу. 
Проведено дослідження синтезованої системи управління на напівнатурній моделі, які доказали існування ковзного режиму в системі керування, високі якості керування в статичних і динамічних режимах, інваріантність до параметричних збурень об'єкта керування.

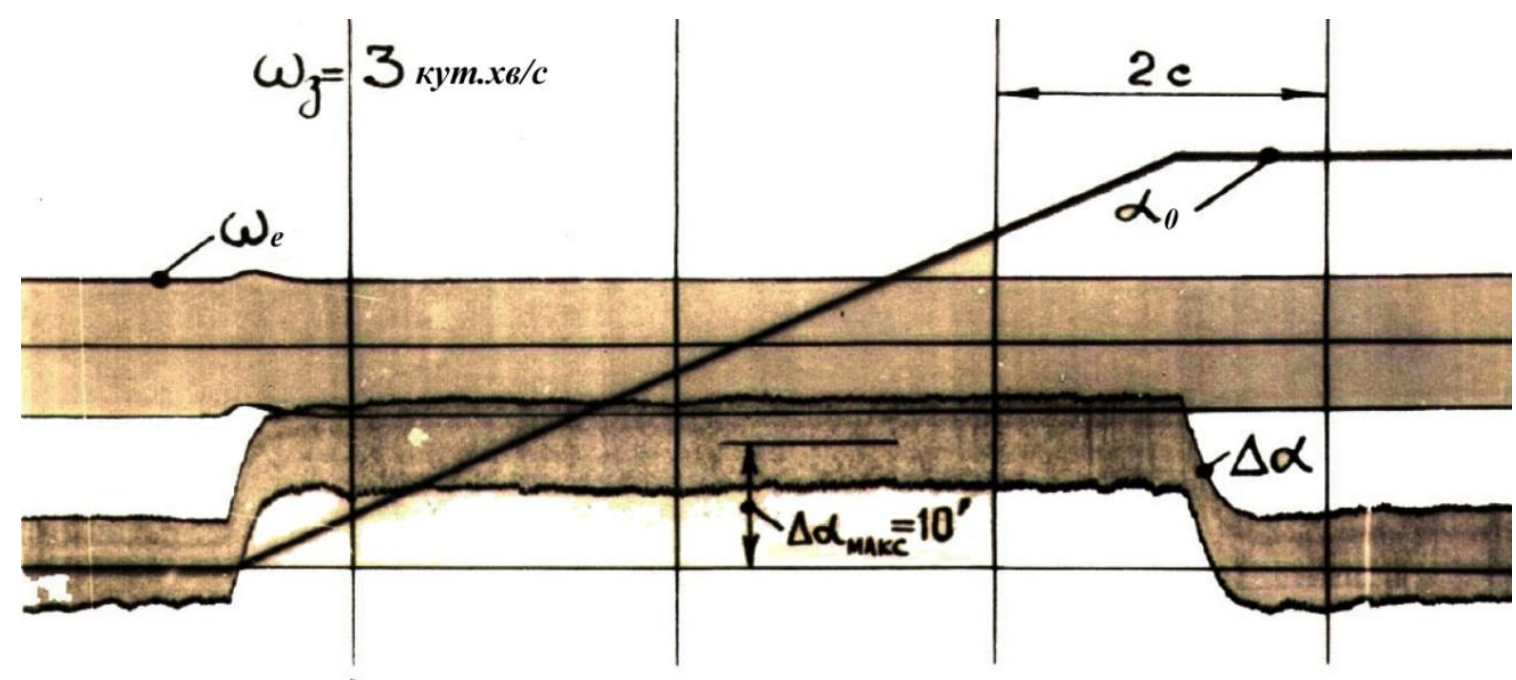

a

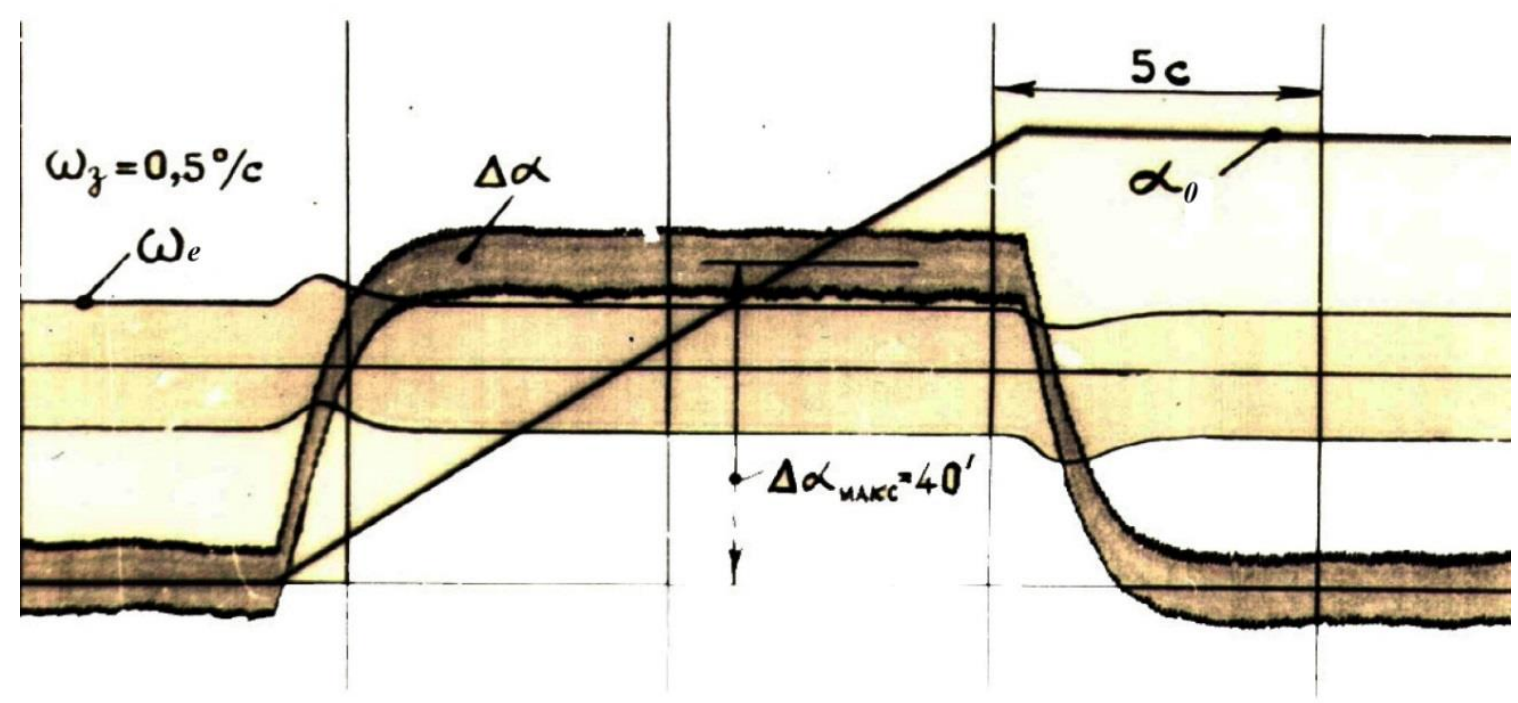

Рис. 8. Графрік відпрацювання слідкування за лінійно змінним кутом завдання (а - швидкість зміни кута 3 кут.хв/с, б - швидкість зміни кута 0,5 кут.град/с)

\section{Список літератури}

1. Козлов, Л. Г. Вдосконалення систем керування гідроприводів 3 LSрегулюванням: автореф. дис... канд. техн. наук: 05.02 .03 / Л. Г. Козлов. Вінниця, 2000. - 19 с.

2. Полешкин, М. С. Гидравлический позиционный привод исполнительных движений механизмов машин: автореф. дис... канд. техн. наук: 05.02 .02 / М. С. Полешкин. - Ростов на Дону, 2013. - 24 с. 
3. Труханов, К. А. Синтез гидропривода с дискретно управляемым движением выходного звена: автореф. дис... канд. техн. наук: 05.04.13 / К. А. Труханов. - М., 2013. - 16 с.

4. Уткин, В. И. Скользящие режимы и их применение в системах с переменной структурой / В. И. Уткин. - М.: Наука, 1974. - 272 с.

5. Синтез электропривода, обладающего низкой чувствительностью к параметрическим возмущениям / А. Б. Зеленов, А. И. Мотченко, А. В. Садовой и др. // Изв.вузов. Электромеханика. - 1982. - №3. - С. $285-291$.

6. Пихай, А. Г. Синтез релейного регулятора по заданому характеристичному рівнянню замкненої системи керування / А. Г. Пихай, А. Б. Жукевич / Електромеханіка. Теорія та практика: праці конференції 3 міжнародною участю. - Львів, 25-28 вересня 1996 року. - С. 154 - 156.

7. Аналитическое конструирование регуляторов, оптимальных по точности и быстродействию / В. В. Сурков, Б. В. Сухинин, В. И. Ловчаков, А. Э. Соловьев. Тул.гос.ун-т. - Тула, 2005. - 230 с.

8. Васильев, А. В. Математическая модель регулируемого электрогидравлического привода [Электронный ресурс] / А. В. Васильев, К. С. Путилин // Гидропневмоавтоматика и гидропривод. Сборник научных трудов. Ковров: ГОУ ВПО «КГТА им.В.А.Дегтярева», 2010. - С.130-147. - Режим доступу: http://pa02.twirpx.net/gidropnevmoavtomatika i gidroprivod 2010.djvu

9. Башта, Т. М. Гидравлические приводы летательных аппаратов / Т. М. Башта. - М.: Машиностроение, 1967. - 499 с.

10. Гамынин, Н. С. Гидравлический привод систем управления / Н. С. Гамынин. - М.: Машиностроение, 1972. - 376 с.

\section{References}

1. Kozlov, L. G. Vdoskonalennya sy`stem keruvannya gidropry`vodiv z LSregulyuvannyam: avtoref. dis... kand. texn. nauk: 05.02.03 / L. G. Kozlov. Vinny`cya, 2000. - 19 s.

2. Poleshkin, M. S. Gidravlicheskii pozitsionnyi privod ispolnitel'nykh dvizhenii mekhanizmov mashin: avtoref. dis... kand. tekhn. nauk: 05.02.02 / M. S. Poleshkin. - Rostov na Donu, 2013. - 24 s.

3. Trukhanov, K. A. Sintez gidroprivoda s diskretno upravlyaemym dvizheniem vykhodnogo zvena: avtoref. dis... kand. tekhn. nauk: 05.04 .13 / K. A. Trukhanov. - M., 2013. - $16 \mathrm{~s}$.

4. Utkin, V. I. Skol'zyashchie rezhimy i ikh primenenie v sistemakh s peremennoi strukturoi / V. I. Utkin. - M.: Nauka, 1974. - 272 s.

5. Sintez elektroprivoda, obladayushchego nizkoi chuvstvitel'nost'yu $k$ parametricheskim vozmushcheniyam / A. B. Zelenov, A. I. Motchenko, A. V. Sadovoi i dr. // Izv.vuzov. Elektromekhanika. - 1982. - №3. - S. 285 - 291.

6. Pyhaj, A. G. Syntez relejnogo reguljatora po zadanomu harakterystychnomu rivnjannju zamknenoi' systemy keruvannja / A. G. Pyhaj, A. B. Zhukevych / Elektromehanika. Teorija ta praktyka: praci konferencii' z mizhnarodnoju uchastju. L'viv, 25-28 veresnja 1996 roku. - S. 154 - 156.

7. Analiticheskoe konstruirovanie regulyatorov, optimal'nykh po tochnosti i bystrodeistviyu / V. V. Surkov, B. V. Sukhinin, V. I. Lovchakov, A. E. Solov'ev. Tul.gos.un-t. - Tula, 2005. - $230 \mathrm{~s}$.

8. Vasil'ev, A. V. Matematicheskaya model' reguliruemogo elektrogidravlicheskogo privoda [Elektronnyi resurs] / A. V. Vasil'ev, K. S. Putilin // 
Gidropnevmoavtomatika i gidroprivod. Sbornik nauchnykh trudov. - Kovrov: GOU VPO «KGTA im.V.A.Degtyareva», 2010. - S.130-147. - Rezhim dostupu: http://pa02.twirpx.net/gidropnevmoavtomatika_i_gidroprivod_2010.djvu

9. Bashta, T. M. Gidravlicheskie privody letatel'nykh apparatov / T. M. Bashta. - M.: Mashinostroenie, 1967. - $499 \mathrm{~s}$.

10. Gamynin, N. S. Gidravlicheskii privod sistem upravleniya / N. S. Gamynin. - M.: Mashinostroenie, 1972. - $376 \mathrm{~s}$.

Поступила в редакцию 20.01.2020, розглянута на редколегії 22.01.2020

\section{Синтез и полунатурное моделирование системы управления гидроприводом со скользящими режимами}

Рассмотрено построение следящего гидропривода объемного регулирования с системой управления релейного типа. Объемный гидропривод используют в сельскохозяйственных, строительных, транспортных машинах, угольных комбайнах, буровых установках, самолетах, военной технике и др. Гидравлические объемные привода имеют ряд преимуществ, важнейшими из которых являются возможность получения больших усилий, плавность хода, малая инерционность гидромашин, сравнительно высокий КПД (до $80 \%$ ), высокая надежность. В то же время ему присущи ряд недостатков, главным из которых является изменение свойств рабочей жидкости в процессе эксплуатации и под воздействием внешних факторов. К недостаткам также можно отнести и потери масла в гидросистеме, загрязнение жидкости в процессе эксплуатации. Указанные недостатки могут привести к потере качества управления, потере точности, скорости отработки заданных управляющих воздействий. Одним из классов систем, которые структурно обеспечивают высокую динамическую точность, есть системы, работающие в скользящем режиме. Кроме того, за счет введения скользящего режима в ряде случаев удается повысить степень астатизма системы, а следовательно, и повысить качество воспроизведения входного задания. Предложена реализация системы управления гидроприводом, инвариантного к параметрическим и внешним возмущениям путем использования скользящих режимов. Для исследования предложенной системы управления гидроприводом построено полунатурную модель разработанной системы, в которой вместо натурного объекта гидропривода используют его математическую модель, в то же время сама система управления реализована физически такой, которая будет использована в реальном устройстве. Полунатурное моделирование позволило ответить на вопросы реализации скользящих режимов при управлении гидроприводом объемного регулирования с помощью электродвигателя постоянного тока. Исследовано поведение системы управления гидроприводом при изменении параметров объекта управления (момента инерции, вязкости масла), которое показало, что изменение коэффициента демпфирования в достаточно широких пределах (до $50 \%$ от расчетного) не приводит к срыву скользящих режимов, качество процессов регулирования существенно не ухудшается. В то же время изменение до $100 \%$ коэфрфициента может привести к неустойчивости системы 
управления, что позволяет сделать вывод о налаживании регулятора положения на меньший из возможных коэффициентов демпфирования. Также предпринято исследование возможности цифровой реализации синтезированного закона управления путем введения в контур управления временной задержки, которая возможна при использовании микропроцессорного вычислителя.

Ключевые слова: гидропривод объемного регулирования; скользящий режим; электродвигатель постоянного тока; инвариантность; полунатурное моделирование; математическая модель, исследование системы со скользящими режимами.

\section{Synthesis and full-scale simulation of a hydraulic control system with sliding modes}

We consider the construction of servo-hydraulic drive of volumetric regulation system control relay type. A volumetric hydraulic actuator is used in agriculture, construction, transport machine, coal harvesters, rigs, airplanes, military machinery, etc. Hydraulic bulk drive have several advantages, most important of which are the possibility of obtaining a great effort, smooth operation, low inertia hydraulic machines, relatively high efficiency (up to $80 \%$ ), high reliability. At the same time, he has a number of drawbacks, chief of which is the change in the properties of the working liquid during operation and under the influence of external factors. The disadvantages include loss of hydraulic oil, contamination of the liquid during operation. These shortcomings can lead to loss of quality control loss of accuracy, speed of working off of the set of control actions. One of the classes of systems which structurally provide high dynamic accuracy, there are systems operating in the sliding mode. In addition, due to the introduction of sliding mode in some cases it is possible to increase the degree of astaticism of the system, and hence to improve the playback quality of the input job. Proposed the implementation of a control system of hydraulic drive, is invariant to parametric and external disturbances through the use of sliding modes. To study the proposed control system with hydraulic drive constructed model of the developed system, which is the natural object of a hydraulic drive using its mathematical model, at the same time the control system is implemented physically is one that can be used in a real device. Hill simulation has allowed answering the questions of realization of sliding modes when controlling hydraulic drive of volumetric regulation through a DC motor. The behavior of a control system of hydraulic drive when changing the parameters of the control object (the moment of inertia, viscosity), which showed that the change of damping ratio within a wide range (up to $50 \%$ of the design) does not disrupt the sliding mode, the quality of the regulatory process does not deteriorate significantly. At the same time, the change to $100 \%$ conversion rate can lead to instability of the control system that allows to make a conclusion about the establishment of the position controller on the lesser of the possible damping coefficients. Also a study of digital implementation of the synthesized control law by introducing in the control loop time delay has been carried out, which is possible with the use of microprocessor-based calculator.

Keywords: hydraulic drive volume control; sliding mode; DC motor; seminatural modeling; mathematical model; study systems with sliding modes. 


\section{Відомості про авторів:}

Жукевич Аркадій Борисович - канд.техн.наук, доцент кафедри Систем управління літальними апаратами, Національний аерокосмічний університет ім. М.Є. Жуковського «Харківський авіаційний інститут», Харків, Україна.

Жукевич Олександр Аркадійович - студент, факультет «Комп'ютерні системи», спеціальності «Штучний інтелект», Харківський Національний Університет Радіоелектроніки, Харків, Україна.

\section{About the Authors:}

Zhukevych Arkadii - Ph.D, Associate Professor, Department of Aircraft Control Systems, National Aerospace University, M. Ye. Zhukovsky "Kharkiv Aviation Institute", Kharkiv, Ukraine, a.zhukevych@khai.edu.

Zhukevych Oleksandr - student, Faculty of Computer Systems, specialty "Artificial Intelligence", Kharkiv National University of Radio Electronics, Kharkiv, Ukraine 